\title{
OPTIMALISASI STRATEGI PEMASARAN DANA PIHAK KETIGA MELALUI PENDEKATAN TEKNIK PERAMALAN EKSPONENTIAL SMOOTHING DI BANK SYARIAH MANDIRI
}

\author{
Susianah Mokhtar \\ Email : susianah@stiem-bongaya.ac.id \\ Manajemen/STIEM Bongaya \\ Jl. Letjen. Pol. A. Mappaoudang No. 28 Makassar \\ Nur Syamsu \\ Email : nursyamsu@stiem-bongaya.ac.id \\ Manajemen/STIEM Bongaya \\ Jl. Letjen. Pol. A. Mappaoudang No. 28 Makassar
}

\begin{abstract}
ABSTRAK
Peramalan merupakan hal yang penting bagi Bank Syariah untuk membantu membuat strategi di masa yang akan datang. Metode peramalan yang tepat dibutuhkan untuk mendapatkan hasil yang maksimal. Exponential Smoothing dengan Holt's method digunakan pada penelitian ini karena memiliki kinerja yang baik dan nilai error yang kecil. Penelitian ini menggunakan data sekunder jumlah Dana Pihak Ketiga yang diperoleh di Bank Syariah Mandiri. Tujuan dari penelitian ini untuk memproyeksikan nilai penjualan yang diharapkan untuk waktu tertentu dan memberikan informasi kepada Bank Syariah agar dapat memformulasikan strategi pemasaran yang efektif. Hasil peramalan diperoleh bahwa peramalan jumlah Dana Pihak Ketiga selama satu tahun yaitu tahun 2020 baik dari akad wadiah dan non profit sharing mengalami peningkatan dari data aktual tahun-tahun sebelumnya. Deposito Non Profit Sharing masih menjadi dana terbesar yang akan berada pada nilai Rp.48.630.000.000.000 dengan probabilitas $95 \%$. Nilai akurasi peramalan pada produk ini sebesar nilai MAPE 2.012141. Untuk Giro Non Profit Sharing dari hasil peramalan merupakan dana terkecil yang akan diperoleh dengan point of forecast $R$ p. 3.451.101.000.000 dengan nilai akurasi peramalan sebesar nilai MAPE 23.83597
\end{abstract}

Kata Kunci: Exponential Smoothing, Holt Method, Dana Pihak Ketiga

\section{ABSTRACT}

Forecasting is important for Islamic banks to help make strategies in the future. The right forecasting method is needed to get maximum results. Exponential Smoothing with Holts method was used in this study because it has good performance and a small error value. This study uses secondary data on the amount of third party funds obtained at Bank Syariah Mandiri. The purpose of this research is to project the expected sales value for a certain time and provide information to Islamic Banks in order to formulate an effective marketing strategy. Forecasting results show that forecasting the amount of Third Party Funds for one year, namely 2020, both from the Wadiah contract and non-profit sharing contracts, has increased from the actual data in previous years. NonProfit Sharing Time Deposits is still the largest fund that will be at a value of IDR 48,630,000,000,000 with a probability of $95 \%$. The value of forecasting accuracy in this product is MAPE 2.012141. For Non-Profit Sharing Current Accounts, the forecasting result is the smallest fund that will be obtained with a point of forecast of $R p .3,451,101,000,000$ with a forecasting accuracy value of 23,83597 MAPE

Keywords: Exponential Smoothing, Holt Method, Third Party Funds 


\section{PENDAHULUAN}

Industri perbankan syariah mulai mengalami evolusi yang awalnya hanya sebagai alternatif bagi masyarakat di perbankan menjadi bagaimana Bank Syariah menempatkan posisinya sebagai pemain utama dalam persaingan lembaga keuangan di tanah air. Dinamika kompetisi antara pemain dalam bank syariah itu sendiri dan bank konvensional semakin ketat. Data Statistik Perbankan Syariah yang dipublikasikan Mei 2019 oleh OJK menunjukkan ada 14 Bank Umum Syariah, 20 Unit Usaha Syariah dengan total kantor BUS dan UUS yang tersebar di Indonesia sejumlah 2.251 serta Bank Perkreditan Syariah sejumlah 164 (Otoritas Jasa Keuangan, 2019). Dibandingkan dengan bank konvensional, market share perbankan syariah $5.7 \%$ dari total perbankan nasional masih jauh tertinggal.

Pertumbuhan setiap bank sangat dipengaruhi oleh perkembangan kemampuannya menghimpun dana masyarakat. Besar kecilnya Dana Pihak Ketiga yang berhasil dihimpun sangat bergantung pada manajemen perbankan itu sendiri. Apabila DPK dalam keadaan stabil maka hal ini akan memberikan tingkat kepastian keputusan dalam pemberian kredit/pembiayaan (Ningrum \& Samrotun, 2019) (Sapar Sapar, Nuraeni Nonji, 2014). Karena semakin besar DPK maka keputusan pemberian pembiayaan akan semakin tinggi pula (Wulan Lestari Oka, 2015). PT. Bank Syariah Mandiri merupakan salah satu bank syariah terbesar di Indonesia yang kinerjanya menjadi tolak ukur penilaian masyarakat akan kinerja bank syariah di Indonesia. PT Bank Syariah Mandiri sampai triwulan I tahun 2019 memperoleh laba bersih sebesar Rp 135 miliar atau naik 43,26\% secara tahunan dari periode sama $2018 \mathrm{Rp}$ 94,4 miliar. Pembiayaan tertinggi dicatat oleh pembiayaan komersial 73,7\% menjadi Rp 7,79 triliun dari periode sama 2018 Rp 4,5 triliun dari lima sektor pembiayaan yaitu komersial, SME, konsumer, mikro dan hasanah card (Assauri, 2015)

Tuntutan masyarakat dan lingkungan pemasaran yang selalu berubah menjadikan pemain yang kuat yang hanya bisa bertahan. Bank syariah yang memiliki kemampuan dalam melakukan keputusan yang tepat untuk menghadapi persaingan yang bisa menjadi pemenangnya. Forecasting merupakan salah satu cara mampu memperkirakan pertumbuhan pasar perbankan syariah.

Peramalan pertumbuhan dana pihak ketiga bertujuan untuk memproyeksikan nilai penjualan yang diharapkan untuk waktu tertentu dan memberikan informasi kepada bank syariah agar dapat memformulasikan strategi pemasaran yang efektif . 
PT. Bank Syariah Mandiri (BSM) merupakan salah satu bank syariah terbesar di Indonesia sehingga kinerja BSM merupakan salah satu tolak ukur penilaian masyarakat akan kinerja bank syariah yang ada di Indonesia. DPK sejak 2013 hingga per Desember 2017 yang dihimpun BSM berhasil tumbuh sebesar 11,37\% (year on year) atau meningkat sebesar Rp 7,95 triliun dari Rp 69,95 triliun per Desember 2016 menjadi Rp 77,90 triliun pada Desember 2017

Metode peramalan untuk melihat pertumbuhan DPK telah dilakukan Ina Nurmalia Kurniati dengan judul Forecasting Pertumbuhan Dana Pihak Ketiga tahun 2015 menggunakan beberapa metode: holt winter additive exponential smoothing, ARIMA, regresi multivariat, dan forecast atas ekspektasi dunia perbankan yang terkandung pada survei kualitatif. Berdasarkan kombinasi forecast yang dilakukan, rata-rata tertimbang dari kombinasi forecast dengan pendekatan regresi menghasilkan hasil yang paling baik (Kurniati, 2015). Sementara Maria Ulfah dengan penelitiannya Analisa Perkembangan Aset, Dana Pihak Ketiga dan Pembiayaan Perbankan Syariah di Indonesia menganalisa dan memprediksi aset, DPK dan pembiayaan menggunakan Autoreggresive Integrated Moving Average (ARIMA) diperoleh hasil bahwa pada periode 2009.III-2010.IV jumlah asset, dana pihak ketiga (DPK), dan pembiayaan perbankan syariah tidak mengalami peningkatan yang berarti dan cenderung stabil. Tingkat pertumbuhan asset, DPK, dan pembiayaan pada periode tersebut mengalami penurunan (Maria, 2010). Raditya Sukmana dan Mahmud Iwan Solihin dengan judul Forecasting Saving Deposit in Malaysian Islamic Banking: Comparison Between Artificial Neural Network and ARIMA. Hasilnya menunjukkan bahwa ANN dapat digunakan sebagai alat prediksi alternatif yang menghasilkan kinerja sedikit lebih baik daripada ARIMA (Sukmana R, 2007).

Metode smoothing merupakan salah satu jenis teknik yang digunakan dalam analisis time series untuk memberikan peramalan jangka pendek. Nilai yang dihaluskan ini kemudian dieksplorasi untuk meramal nilai masa depan. ARIMA (Autoregressive Integrated Moving Average) dan Penghalusan Eksponential (Exponential Smoothing) merupakan metode penghalusan yang digunakan dalam melakukan peramalan. Penggunaan Exponential Smoothing dengan metode Holt Winters digunakan pada penelitian ini karena metode ini sangat baik meramalkan pola data yang berpengaruh musiman dengan unsur trend yang timbul secara bersamaan, metode yang sederhana dan mudah dimasukkan ke dalam praktek dan kompetitif terhadap model peramalan yang 
lebih rumit dan metode ini lebih baik dari metode ARIMA. Ini dibuktikan pada beberapa penelitian terdahulu yang membandingkan peramalan menggunakan metode Exponential Smoothing Holt Winters dan ARIMA. Penelitian yang dilakukan Tias Safitri, Nurkaromah Dwidayati, Sugiman dengan judul Perbandingan Peramalan Menggunakan Metode Exponential Smoothing Holt Winters dan ARIMA menunjukkan lebih tepat menggunakan metode exponential smoothing Holt-Winters daripada ARIMA karena menghasilkan nilai error lebih kecil daripada nilai error metode ARIMA (Tias Safitri, Nurkaromah Dwidayati, 2017) Perbandingan Peramalan Metode Moving Average dan Exponential Smoothing Holt Winter Untuk Menentukan Peramalan Inflasi di Indonesia oleh Yuseva Rismawanti, Moh Yamin Darsyah didapatkan metode yang paling baik adalah metode exponential smoothing holt winter (Yuseva Rismawanti, 2018)

\section{METODE PENELITIAN}

\section{Diagram Alir}

Gambar 2 merupakan tahapan yang harus dilaksanakan dalam penelitian ini. Secara garis besar terdapat 2 tahap dengan uraian sebagai berikut:

1.1. Tahap persiapan

a. Studi literatur yaitu Mengumpulkan danmengkaji literaturmengenai peramalan dana pihak ketiga dengan exponential smoothing

b. Pengumpulan data yaitu Mengumpulkan data dana pihak ketiga pada Bank Syariah Mandiri beserta varibal penelitian yang diperlukan

\subsection{Tahap Analisis}

a. Melakukan Manajemen dan Eksplorasi data yang diperoleh dari Portal Website Bank Mandiri Syariah dengan analisis deskriptif berupa Tabel maupun Grafik terhadap semua variabel yang berkaitan dengan dana pihak ketiga.

b. Melakukan Analisis Statistika Inferensial berupa peramalan kuantitatif dengan metode peramalan exponential smoothing dengan pengolahan data menggunakan R Studio

c. Metode akan mengeluarkan nilai Mean Square Error (MSE), Mean Absolute Deviation (MAD), Mean Absolute Percentage Error (MAPE), dan Root Mean Square Error (RMSE) untuk mengukur tingkat akurasi peramalan. 


\section{Jenis dan Sumber Data}

Jenis penelitian merupakan penelitian terapan dengan menerapkan metode peramalan exponential smoothing. Sumber data yang digunakan pada penelitian ini adalah data sekunder diperoleh dari website PT Bank Mandiri Syariah dari 2017 sampai dengan 2019

\section{Analisis Data}

Analisis data dilakukan untuk memberikan interpretasi baik secara deskriptif maupun secara inferensial terhadap dana pihak ketiga (DPK) Bank Mandiri Syariah menggunakan exponential smoothing dengan metode Holt's.

\section{HASIL DAN PEMBAHASAN}

\section{Hasil}

\section{Data Dana Pihak Ketiga}

Data yang digunakan pada penelitian ini adalah data dana pihak ketiga (DPK) pada Bank Syariah Mandiri periode tahun 2017-2019. Data diperoleh dari laporan keuangan Bank Syariah Mandiri. Data produk dana pihak ketiga dengan akad wadiah dan non profit sharing ditunjukkan pada Tabel 1 :

Tabel 1 Dana Pihak Ketiga Bank Mandiri Syariah

Periode 2017-2019

\begin{tabular}{crrrrr}
\hline & \multicolumn{2}{c}{ Wadiah } & \multicolumn{3}{c}{ Non Profit Sharing } \\
\cline { 2 - 6 } Bulan & \multicolumn{1}{c}{ Giro } & Tabungan & Giro & Tabungan & Deposito \\
\hline Jan-17 & 6.096 .577 & 2.579 .424 & 61.268 & 25.031 .891 & 36.473 .336 \\
Feb-17 & 6.174 .982 & 2.585 .812 & 60.798 & 25.023 .119 & 36.729 .318 \\
Mar-17 & 7.530 .315 & 2.647 .623 & 77.495 & 25.176 .760 & 35.603 .392 \\
Apr-17 & 12.453 .358 & 2.655 .882 & 91.841 & 24.704 .780 & 34.008 .191 \\
Mei-17 & 8.642 .361 & 2.660 .932 & 110.724 & 24.662 .516 & 34.310 .767 \\
Jun-17 & 8.751 .773 & 2.789 .864 & 278.761 & 25.006 .872 & 35.472 .421 \\
Jul-17 & 8.542 .983 & 2.850 .989 & 248.617 & 25.819 .477 & 36.185 .807 \\
Ags-17 & 7.273 .917 & 2.870 .785 & 252.759 & 25.930 .074 & 36.251 .611 \\
Sep-17 & 8.685 .435 & 2.889 .215 & 257.856 & 26.103 .529 & 36.814 .683 \\
Okt-17 & 6.970 .510 & 2.966 .481 & 218.063 & 26.271 .338 & 37.536 .934 \\
Nov-17 & 6.979 .850 & 3.036 .609 & 218.421 & 26.742 .606 & 37.670 .044 \\
Des-17 & 8.435 .776 & 3.193 .558 & 525.284 & 28.200 .736 & 37.547 .789 \\
Jan-18 & 8.350 .480 & 3.176 .001 & 300.762 & 28.056 .078 & 38.389 .322 \\
Feb-18 & 8.473 .568 & 3.159 .089 & 300.843 & 28.184 .049 & 39.918 .089 \\
Mar-18 & 9.003 .749 & 3.190 .692 & 427.684 & 28.691 .501 & 41.270 .530 \\
Apr-18 & 8.578 .978 & 3.197 .408 & 459.586 & 27.928 .403 & 42.155 .357 \\
Mei-18 & 10.075 .186 & 3.293 .319 & 452.661 & 28.025 .681 & 39.816 .010 \\
Jun-18 & 10.642 .088 & 3.335 .423 & 513.494 & 28.408 .924 & 39.516 .575 \\
Jul-18 & 8.624 .108 & 3.396 .155 & 502.870 & 28.966 .438 & 39.847 .385 \\
Ags-18 & 8.483 .311 & 3.423 .311 & 470.375 & 29.257 .422 & 40.298 .853 \\
Sep-18 & 7.928 .988 & 3.402 .430 & 552.117 & 29.583 .338 & 40.808 .585 \\
Okt-18 & 7.768 .409 & 3.463 .075 & 520.727 & 29.870 .877 & 41.210 .985 \\
Nov-18 & 7.844 .020 & 3.550 .287 & 633.753 & 29.985 .015 & 40.222 .899 \\
Des-18 & 8.704 .173 & 3.751 .591 & 682.242 & 31.318 .420 & 43.015 .417 \\
Jan-19 & 8.469 .652 & 3.731 .625 & 682.167 & 31.153 .845 & 42.443 .170 \\
Feb-19 & 8.780 .865 & 3.806 .231 & 702.615 & 31.109 .637 & 42.210 .667
\end{tabular}




\begin{tabular}{rrrrrr} 
Mar-19 & 10.266 .433 & 3.858 .281 & 686.007 & 31.390 .520 & 40.953 .525 \\
Apr-19 & 11.230 .181 & 3.925 .077 & 700.079 & 31.177 .326 & 39.825 .494 \\
Mei-19 & 10.084 .191 & 4.274 .170 & 867.422 & 31.589 .446 & 39.098 .534 \\
Jun-19 & 9.948 .942 & 4.230 .036 & 1.140 .395 & 32.100 .883 & 39.934 .595 \\
Jul-19 & 9.165 .511 & 4.348 .141 & 1.105 .076 & 32.344 .806 & 39.941 .150 \\
Ags-19 & 8.991 .775 & 4.378 .915 & 494.776 & 32.632 .297 & 41.085 .943 \\
Sep-19 & 9.116 .519 & 4.514 .458 & 1.041 .525 & 33.072 .715 & 42.749 .100 \\
Okt-19 & 9.898 .888 & 4.614 .763 & 1.092 .687 & 32.730 .617 & 43.953 .328 \\
Nov-19 & 10.227 .741 & 4.784 .514 & 1.131 .830 & 33.356 .435 & 43.544 .134 \\
Des-19 & 11.510 .301 & 5.126 .726 & 2.969 .821 & 34.673 .426 & 45.529 .456 \\
\hline
\end{tabular}

\section{Deskripsi Data Pembiayaan}

Analisis deskriptif memberikan gambaran data jumlah Dana Pihak Ketiga yang terhimpun dari produk baik itu akad wadiah maupun Non Profit Sharing. Pada tabel 2 menunjukkan dekriptif statistiknya sebagai berikut :

\section{Tabel 2 Data Deskriptif Dana Pihak Ketiga}

\begin{tabular}{rrrrrr}
\hline \multirow{2}{*}{ Statistics } & \multicolumn{2}{c}{ Wadiah } & \multicolumn{3}{c}{ Non Profit Sharing } \\
\cline { 2 - 6 } & \multicolumn{1}{c}{ Giro } & \multicolumn{1}{c}{ Tabungan } & \multicolumn{1}{c}{ Giro } & \multicolumn{1}{c}{ Tabungan } & \multicolumn{1}{c}{ Deposito } \\
\hline nobs & 36.000000 & 36.000000 & 36.000000 & 36.000000 & 36.000000 \\
NAs & 0.000000 & 0.000000 & 0.000000 & 0.000000 & 0.000000 \\
Minimum & 6.096577 & 2.579424 & 0.060798 & 24.662516 & 34.008191 \\
Maximum & 12.453358 & 5.126726 & 2.969821 & 34.673426 & 45.529456 \\
1. Quartile & 8.245107 & 2.947164 & 0.256582 & 26.229386 & 37.356371 \\
3. Quartile & 9.911402 & 3.874980 & 0.689525 & 31.336445 & 41.225871 \\
Mean & 8.852942 & 3.490525 & 0.578706 & 29.007828 & 39.509539 \\
Median & 8.663898 & 3.365789 & 0.498823 & 28.828969 & 39.882737 \\
Sum & 318.705894 & 125.658892 & 20.833401 & 1044.281797 & 1422.343396 \\
SE Mean & 0.233296 & 0.113847 & 0.086364 & 0.483064 & 0.470939 \\
LCL Mean & 8.379325 & 3.259403 & 0.403378 & 28.027155 & 38.553481 \\
UCL Mean & 9.326558 & 3.721647 & 0.754034 & 29.988500 & 40.465597 \\
Variance & 1.959374 & 0.466603 & 0.268514 & 8.400636 & 7.984224 \\
Stdev & 1.399777 & 0.683083 & 0.518183 & 2.898385 & 2.825637 \\
Skewness & 0.334798 & 0.588168 & 2.701341 & 0.046492 & -0.077370 \\
Kurtosis & 0.049415 & -0.671047 & 9.899602 & -1.254491 & -0.796036 \\
\hline
\end{tabular}

Tabel 2 menunjukkan nilai rata-rata jumlah giro wadiah adalah 8.85 yang artinya jumlah dana yang diperoleh setiap bulan Rp.8.850.000.000.000 Untuk tabungan wadiah mean 3.36 yang artinya jumlah dana yang diperoleh setiap bulannya Rp. 3.360.000.000. 000 Pada produk giro non profit sharing nilai rata-rata adalah 0.57 yang artinya jumlah dana sebesar Rp. 570.000.000.000 tabungan nilai rata-rata 29.00 hal ini berarti rata-rata setiap bulan menerima dana sebesar Rp. 29.000.000.000.000 serta deposito nilai rataratanya 39.51 yang berarti jumlah dana deposito rata-rata Rp. 39.510.000.000.000 
Jumlah dana pihak ketiga yang terkecil dari semua produk dana pihak ketiga yaitu pada produk giro non profit sharing sebesar 0.06 atau Rp. 60.798.000.000 pada bulan Februari 2017 sementara produk dengan jumlah dana terbesar pada deposito non profit sharing sebesar Rp. 45.529.456.000.000 pada bulan Desember 2019 dalam kurun waktu 30 bulan.

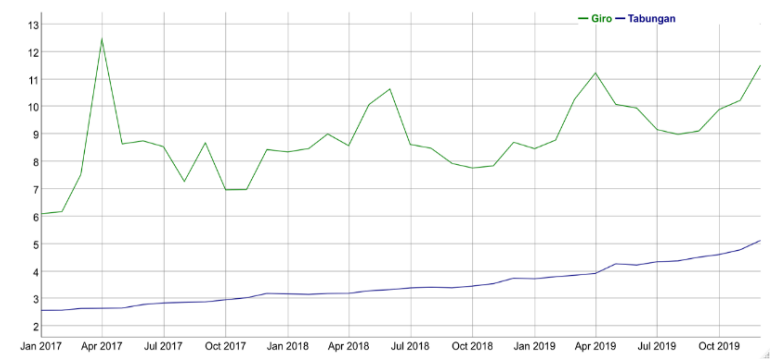

\section{Gambar 1 Summary and Plot Series Wadiah}

. Gambar 1 menunjukkan grafik pergerakan data series umtuk produk Dana Pihak Ketiga untuk akad wadiah. Jumlah giro setiap bulannya mengalami fluktuasi setiap bulannya namun dari tahun ke tahun mengalami peningkatan. Jumlah giro paling banyak di tahun 2017. Untuk tabungan pertumbuhannya dari tahun ke tahun meningkat. Secara keseluruhan jumlah giro lebih banyak dibandingkan tabungan.

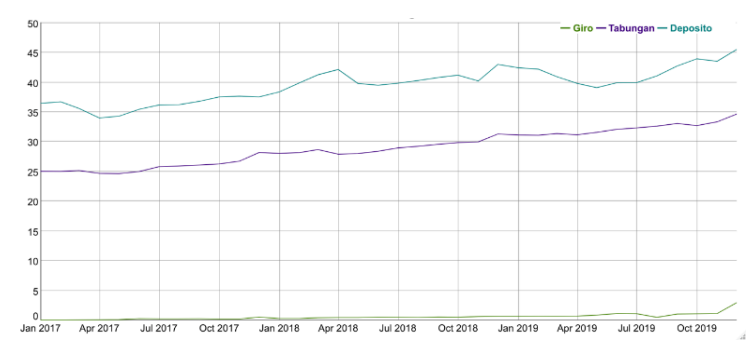

\section{Gambar 2 Summary and Plot Series Non Profit Sharing}

Gambar 2 menunjukkan grafik pergerakan data series umtuk produk Dana Pihak Ketiga untuk Non Profit Sharing. Jumlah giro, tabungan dan deposito mengalami peningkatan setiap tahunnya. Namun pertumbuhan giro tidak begitu signifikan dibandingkan tabungan dan deposito. Secara keseluruhan jumlah dana deposito yang berhasil dihimpun lebih banyak dibandingkan tabungan dan giro.

\section{Peramalan}

Peramalan data kuantitatif dilakukan dengan metode Exponential Smoothing dengan Holt's method karena memmiliki kinerja yang baik dan dengan nilai error yang kecil. Peramalan 
dilakukan masing-masing produk Dana Pihak Ketiga akad wadiah dan akad Non Profit Sharing

\subsection{Wadiah}

\subsubsection{Giro}

Peramalan giro wadiah dilakukan selama satu tahun kedepan. Gambar 3 menunjukkan grafik data awal dari bulan Januari 2017 sampai dengan Desember 2019 dan hasil peramalan dari bulan Januari 2020 sampai dengan Desember 2020. Terlihat grafik menunjukan fluktuasi data penjualan namun data peramalan meningkat konstan.

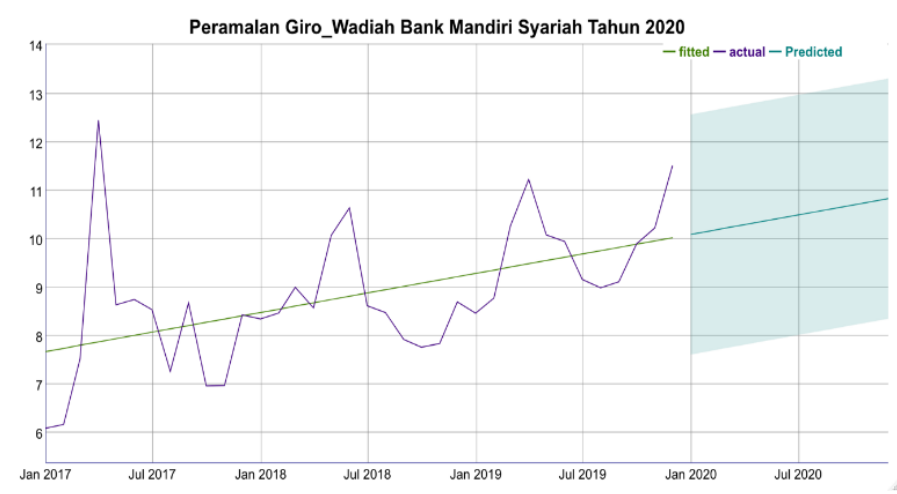

Gambar 3 Grafik Hasil Forecast Giro

Tabel 3 Hasil Forecasting

\begin{tabular}{cccc}
\hline Tanggal & Forecast & Lower 95\% & Upper 95\% \\
\hline $01-01-2020$ & 10.09388 & 7.618378 & 12.56938 \\
$01-02-2020$ & 10.16102 & 7.685523 & 12.63653 \\
$01-03-2020$ & 10.22817 & 7.752668 & 12.70367 \\
$01-04-2020$ & 10.29531 & 7.819813 & 12.77082 \\
$01-05-2020$ & 10.36246 & 7.886958 & 12.83796 \\
$01-06-2020$ & 10.42960 & 7.954102 & 12.90511 \\
$01-07-2020$ & 10.49675 & 8.021246 & 12.97225 \\
$01-08-2020$ & 10.56389 & 8.088391 & 13.03940 \\
$01-09-2020$ & 10.63104 & 8.155535 & 13.10654 \\
$01-10-2020$ & 10.69818 & 8.222678 & 13.17369 \\
$01-11-2020$ & 10.76533 & 8.289822 & 13.24084 \\
$01-12-2020$ & 10.83247 & 8.356965 & 13.30798 \\
\hline
\end{tabular}

Tabel 3 menunjukkan data hasil peramalan beserta selang interval ramalan selama 1 tahun kedepan pada tahun 2020. Untuk produk giro wadiah jumlah dana meningkat setiap bulan hingga akhir tahun 2020 dengan selang kepercayaan yang sama. Jumlah dana yang terbesar diperoleh Bank Mandiri Syariah di bulan Desember 2020 sebesar Rp.10.832.470.000.000

Tabel 4 Evaluasi Model

\begin{tabular}{lllllll}
\hline Evaluasi & ME & RMSE & MAE & MPE & MAPE & MASE \\
\hline
\end{tabular}




\begin{tabular}{ccccccc}
\hline Model & \multicolumn{7}{c}{} \\
\hline Giro & 0.0006562095 & 1.1908 & 0.8712414 & -1.745262 & 9.89457 & 0.9794063 \\
\hline
\end{tabular}

Pada tabel 4 metode perhitungan dengan menggunakan Holt diperoleh nilai akurasi peramalan sebesar ME 0.00065, nilai RMSE 1.1908, nilai MAE 0.8712414, nilai MPE, nilai MASE 0.9794063. Nilai MAPE $9.89 \%$ dibawah 10\% menunjukkan peramalan sangat baik.

\subsubsection{Tabungan}

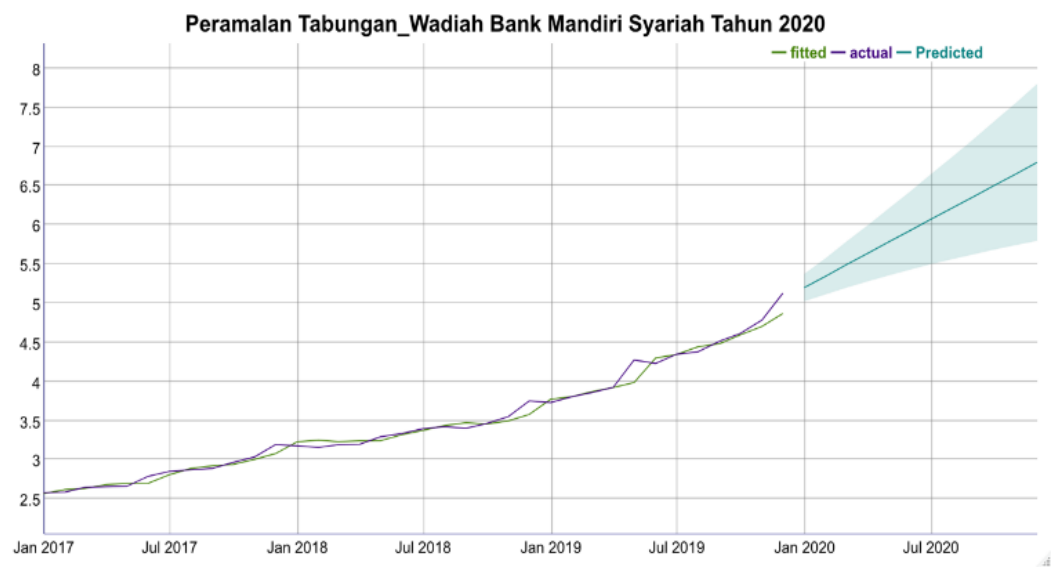

\section{Gambar 4 Grafik Hasil Forecast Jumlah Tabungan}

Gambar 4 menunjukkan grafik data awal dari bulan Januari 2017 sampai dengan Desember 2019 dan hasil peramalan dari bulan Januari 2020 sampai dengan Desember 2020

Tabel 5 Hasil Forecasting

\begin{tabular}{ccrrr}
\hline \multicolumn{1}{c}{ Tanggal } & Forecast & Lower 95\% & Upper 95\% \\
\hline $01-01-2020$ & 5.199536 & 5.024825 & 5.374247 \\
$01-02-2020$ & 5.344889 & 5.113078 & 5.576700 \\
$01-03-2020$ & 5.490241 & 5.197406 & 5.783076 \\
$01-04-2020$ & 5.635593 & 5.277845 & 5.993341 \\
$01-05-2020$ & 5.780946 & 5.354515 & 6.207377 \\
$01-06-2020$ & 5.926298 & 5.427556 & 6.425040 \\
$01-07-2020$ & 6.071650 & 5.497111 & 6.646190 \\
$01-08-2020$ & 6.217003 & 5.563310 & 6.870695 \\
$01-09-2020$ & 6.362355 & 5.626279 & 7.098431 \\
$01-10-2020$ & 6.507707 & 5.686128 & 7.329287 \\
$01-11-2020$ & 6.653060 & 5.742961 & 7.563158 \\
$01-12-2020$ & 6.798412 & 5.796873 & 7.799950 \\
\hline
\end{tabular}

Tabel 5 menunjukkan data hasil peramalan selama 1 tahun kedepan pada tahun 2020 untuk produk tabungan wadiah meningkat setiap bulan dengan selang kepercayaan yang berbeda-beda. 
Tabel 6 Evaluasi Model

\begin{tabular}{lllllll}
\hline Evaluasi Model & ME & RMSE & MAE & MPE & MAPE & MASE \\
\hline Tabungan & 0.01915553 & 0.08404185 & 0.0551126 & 0.4243763 & 1.515882 & 0.6923192 \\
\hline
\end{tabular}

Untuk peramalan selama tahun 2020 menggunakan Holt menghasilkan nilai akurasi peramalan dengan nilai ME sebesar 0.01915553, nilai RMSE 0.08404185, nilai MAE 0.0551126, nilai MPE 0.4243763, nilai MAPE 1.51\% menunjukkan peramalan sangat baik karena nilainya dibawah $10 \%$ dan nilai MASE 0.6923192

\subsection{Non Profit Sharing}

\subsubsection{Giro}

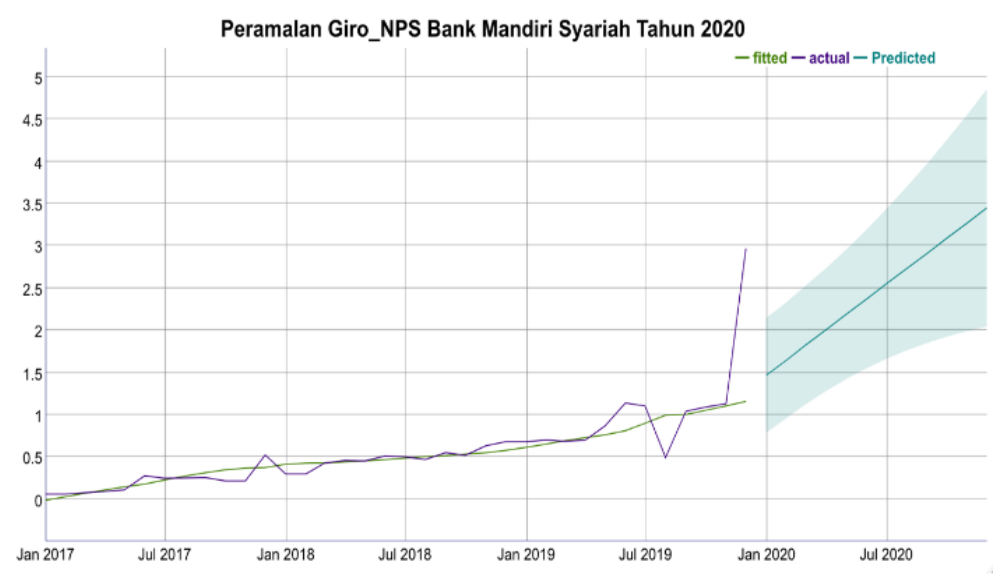

Gambar 5 Grafik Hasil Forecast Giro

Gambar 5 merupakan grafik hasil ramalan pada giro dari bulan Januari 2020 sampai dengan Desember 2020. Pada tabel 7 memperlihatkan hasil forecast dengan selang kepercayaan yang setiap bulannya cenderung semakin panjang setelah pertengahan tahun . Awal tahun 2020 hasil peramalan menunjukkan jumlah pembiayaan sejumlah Rp.1.468.000.000.000 dan hingga akhir tahun 2020 meningkat sebesar Rp.3.450.000.000.000 Giro pada investasi non profit sharing diprediksi tumbuh cukup bagus dibandingkan periode tahun-tahun sebelumnya

Tabel 7 Hasil Forecasting

\begin{tabular}{cccc}
\hline Tanggal & Point Forecast & Lower 95\% & Upper 95\% \\
\hline $01-01-2020$ & 1.468325 & 0.7897274 & 2.146922 \\
$01-02-2020$ & 1.648577 & 0.9631532 & 2.334001 \\
$01-03-2020$ & 1.828830 & 1.1282890 & 2.529370 \\
$01-04-2020$ & 2.009082 & 1.2824434 & 2.735721 \\
$01-05-2020$ & 2.189334 & 1.4236967 & 2.954972 \\
$01-06-2020$ & 2.369587 & 1.5510482 & 3.188125 \\
$01-07-2020$ & 2.549839 & 1.6643606 & 3.435318 \\
$01-08-2020$ & 2.730092 & 1.7641424 & 3.696041 \\
\hline
\end{tabular}




\begin{tabular}{llll}
\hline $01-09-2020$ & 2.910344 & 1.8512795 & 3.969408 \\
$01-10-2020$ & 3.090596 & 1.9268063 & 4.254386 \\
$01-11-2020$ & 3.270849 & 1.9917541 & 4.549943 \\
$01-12-2020$ & 3.451101 & 2.0470711 & 4.855131 \\
\hline
\end{tabular}

Model Holt dalam peramalan giro non profit sharing memiliki nilai akurasi sebesar ME 0.05820911, RMSE 0.3264284, nilai MAE 0.1276647, MPE 1.030678, MASE 0.8961829. Nilai MAPE $23.83 \%$ menunjukkan nila peramalan baik karena berada diantara $10 \%$ dan $20 \%$.

Tabel 8 Evaluasi Model

\begin{tabular}{cllllll}
\hline $\begin{array}{l}\text { Evaluasi } \\
\text { Model }\end{array}$ & ME & RMSE & MAE & MPE & MAPE & MASE \\
\hline Giro & 0.05820911 & 0.3264284 & 0.1276647 & 1.030678 & 23.83597 & 0.8961829 \\
\hline
\end{tabular}

\subsubsection{Tabungan}

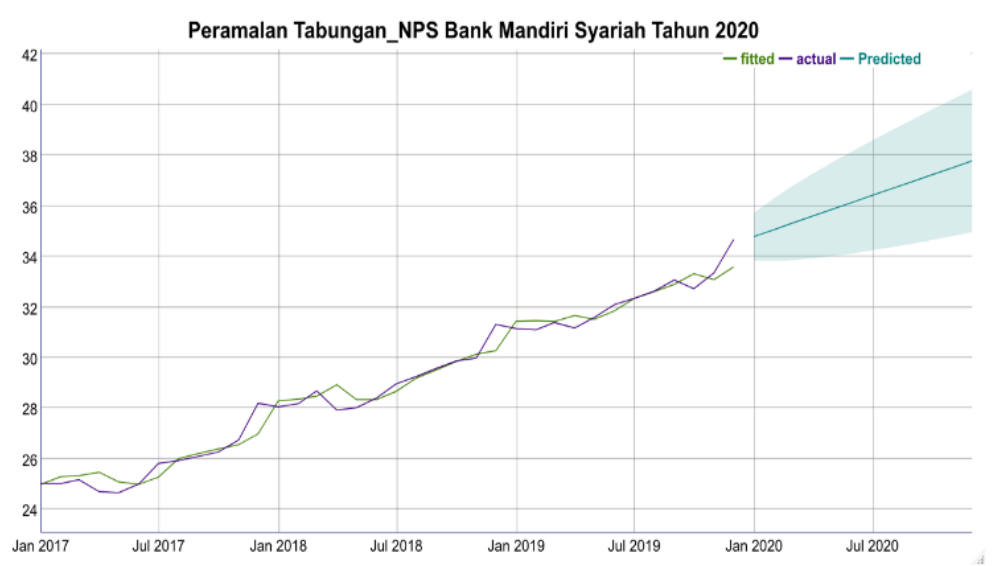

Gambar 6 Grafik Hasil Forecast Jumlah Tabungan

Tabel 9 menunjukkan data hasil peramalan beserta selang interval ramalan selama 1 tahun kedepan pada tahun 2020. Untuk tabungan pada non profit sharing meningkat setiap bulan hingga akhir tahun 2020 yang berada diantara selang kepercayaan Lo_95 sampai dengan Hi_95 dengan selang kepercayaan yang berbeda-beda. Pada tabel 9 terlihat bahwa setiap bulan rentang selang kepercayaan semakin panjang. Hasil peramalan di awal tahun 2020 tabungan sebesar Rp. 34.780.000.000.000 dan cenderung meningkat setiap bulannya hingga akhir tahun 2020 sebesar Rp. 37.780.000.000.000

Tabel 9 Hasil Forecast

\begin{tabular}{cccc}
\hline Tanggal & Point Forecast & Lo 95 & Hi 95 \\
\hline $01-01-2020$ & 34.78892 & 33.85307 & 35.72477 \\
\hline
\end{tabular}




\begin{tabular}{llll}
\hline $01-02-2020$ & 35.06122 & 33.82970 & 36.29275 \\
$01-03-2020$ & 35.33352 & 33.86463 & 36.80242 \\
$01-04-2020$ & 35.60582 & 33.93287 & 37.27878 \\
$01-05-2020$ & 35.87812 & 34.02338 & 37.73287 \\
$01-06-2020$ & 36.15042 & 34.13015 & 38.17070 \\
$01-07-2020$ & 36.42272 & 34.24945 & 38.59599 \\
$01-08-2020$ & 36.69502 & 34.37881 & 39.01123 \\
$01-09-2020$ & 36.96732 & 34.51646 & 39.41818 \\
$01-10-2020$ & 37.23962 & 34.66110 & 39.81814 \\
$01-11-2020$ & 37.51192 & 34.81174 & 40.21210 \\
$01-12-2020$ & 37.78422 & 34.96761 & 40.60083 \\
\hline
\end{tabular}

Metode Holt untuk peramalan dana pihak ketiga pada tabungan investasi non profit sharing memiliki nilai akurasi peramalan sebesar ME 8.503711e-05, nilai RMSE 0.4501757, nilai MAE sebesar 0.3117259 , nilai MPE -0.04141026, nilai MASE 0.7775803. Nilai MAPE 1.07\% menunjukkan hasil peramalan yang akurat

\section{Tabel 10 Evaluasi Model}

\begin{tabular}{lllllll}
\hline $\begin{array}{l}\text { Evaluasi } \\
\text { Model }\end{array}$ & ME & RMSE & MAE & MPE & MAPE & MASE \\
\hline Tabungan & $8.503711 \mathrm{e}-05$ & 0.4501757 & 0.3117259 & -0.04141026 & 1.075275 & 0.7775803 \\
\hline
\end{tabular}

\subsubsection{Deposito}

Gambar 11 menunjukkan grafik data awal dari bulan Januari 2017 sampai dengan Desember 2019 dan pergerakan peramalan dari bulan Januari 2020 sampai dengan Desember 2020 


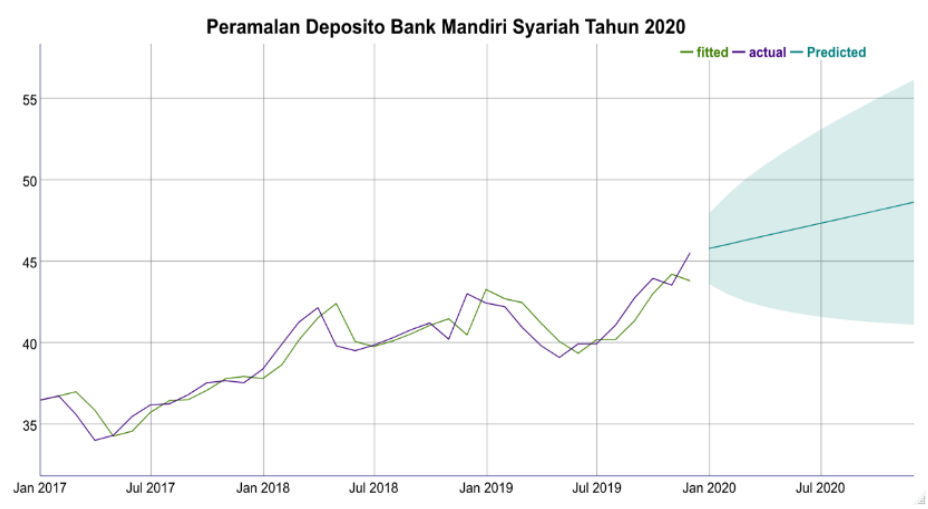

Gambar 7 Grafik Hasil Forecast Deposito

Pada tabel 11 memperlihatkan hasil forecast dengan selang kepercayaan yang setiap bulannya semakin panjang. Awal tahun 2020 hasil peramalan menunjukkan jumlah pembiayaan sejumlah Rp. 45.780.000.000.000 dan hingga akhir tahun 2020 meningkat sebesar Rp. 48.630.000.000.000

Tabel 11 Hasil Forecast

\begin{tabular}{cccc}
\hline Tanggal & Point Forecast & Lower 95\% & Upper 95\% \\
\hline $01-01-2020$ & 45.78779 & 43.61874 & 47.95685 \\
$01-02-2020$ & 46.04630 & 42.97879 & 49.11380 \\
$01-03-2020$ & 46.30481 & 42.54777 & 50.06184 \\
$01-04-2020$ & 46.56332 & 42.22488 & 50.90175 \\
$01-05-2020$ & 46.82182 & 41.97109 & 51.67256 \\
$01-06-2020$ & 47.08033 & 41.76637 & 52.39429 \\
$01-07-2020$ & 47.33884 & 41.59883 & 53.07885 \\
$01-08-2020$ & 47.59735 & 41.46073 & 53.73397 \\
$01-09-2020$ & 47.85585 & 41.34667 & 54.36504 \\
$01-10-2020$ & 48.11436 & 41.25274 & 54.97598 \\
$01-11-2020$ & 48.37287 & 41.17599 & 55.56975 \\
$01-12-2020$ & 48.63138 & 41.11411 & 56.14865 \\
\hline
\end{tabular}

Untuk peramalan deposito non profit sharing akurasi peramalan diperoleh nilai sebesar ME 0.0003570538, RMSE sebesar 1.043388, nilai MAE 0.8042609, nilai MPE -0.05710537 , nilai MASE 0.9184423. Nilai MAPE 2.01\% menunjukkan nilai peramalan yang sangat baik.

Tabel 12 Evaluasi Model

\begin{tabular}{lllllll}
\hline $\begin{array}{l}\text { Evaluasi } \\
\text { Model }\end{array}$ & ME & RMSE & MAE & MPE & MAPE & MASE \\
\hline Deposito & 0.0003570538 & 1.043388 & 0.8042609 & -0.05710537 & 2.012141 & 0.9184423 \\
\hline
\end{tabular}




\section{Hasil Peramalan dan Implikasinya Terhadap Strategi Pemasaran}

Secara umum pertumbuhan dana pihak ketiga berada pada kinerja yang baik. Kinerja yang baik ini sejalan dengan implementasi strategi-strategi yang dilakukan oleh Bank Mandiri Syariah yakni pertumbuhan bisnis yang sehat dan sustain, penyelesaian kualitas pembiayaan, peningkatan fee based income, produktivitas dan contribution margin. Dana murah dan deposito berbanding sama pada komposisi dana pihak ketiga selama kurun waktu 3 tahun.

Peramalan dengan menggunakan Exponential Smoothing dengan Holt's method menunjukkan Dana Pihak Ketiga baik akad wadiah maupun dari non profit sharing mengalami peningkatan di tahun 2020 lebih baik dari periode sebelumnya. Pertumbuhan Giro Wadiah selama tahun 2020 meningkat dan lebih baik dari tahun sebelumnya. Begitu juga dengan tabungan wadiah pada hasil peramalan. Jumlah dana giro wadiah masih lebih besar dibandingkan tabungan wadiah. Untuk akad non profit sharing dana deposito masih sama seperti tahun sebelumnya, tetap mendominasi dibandingkan tabungan dan giro baik pada akad wadiah maupun non profit sharing. Dana giro di awal tahun peramalan terjadi penurunan namun perlahan tumbuh setiap bulannya selama tahun 2020. Keakuratan peramalan yang dilihat dari parameter nilai ME, RMSE, MAE, MPE, MAPE dan MASE rata-rata menunjukkan nilai parameter rendah atau nilai error kecil. Ini menunjukkan metode Exponential Smoothing dengan Holts dapat digunakan meramal pertumbuhan dana pihak ketiga pada Bank Syariah Mandiri karena menghasilkan tingkat akurasi yang sangat baik.

Dari hasil peramalan strategi yang perlu dirancang oleh Bank Syariah Mandiri untuk mempertahankan dan meningkatkan kinerja pertumbuhan Dana Pihak Ketiga

1. Meningkatkan literasi dan inklusi produk-produk Bank Syariah Mandiri

Rendahnya jumlah dana murah yaitu tabungan dan giro disebabkan minimnya literasi masyarakat. Perbedaan bank syariah dan konvensional memicu terjadinya perbedaan prinsip yang dianut oleh bank syariah dan konvensional. Salah satunya ialah tentang pemberian bunga kepada nasabah yang menabung di bank. Pada bank konvensional, bunga diberikan bank kepada nasabah sebagai imbal jasa atas pinjaman uang. Namun pada prinsip Islam, bunga dianggap sebagai riba, sehingga bank syariah tidak membagikan bunga kepada nasabah. Sebagai gantinya, bank syariah melakukan 
sistem bagi hasil alias membagi pendapatan yang diperoleh bank kepada para nasabah. Sistem penghitungan ini dinilai cukup rumit oleh sebagian besar masyarakat. Apalagi terdapat berbagai jenis usaha yang dilakukan oleh bank syariah, dan semuanya dihitung dan dilakukan berdasarkan prinsip Islam yang masih awam di mata masyarakat. Hal ini mengakibatkan bank syariah khusunya produk pendanaan kurang diminati oleh kebanyakan orang. Bank Syariah Mandiri perlu melakukan literasi

2. Meningkatkan market share dana murah yaitu tabungan dan giro

Data aktual dan hasil peramalan menunjukkan deposito mendominasi komposisi dana pihak ketiga di Bank Syariah Mandiri. Konsekuensi dari besarnya deposito, BSM mengeluarkan biaya dana yang besar dibandingkan tabungan dan giro. Mandiri Syariah perlu meningkatkan kerjasama dengan institusi dalam hal mendongkrak penjualan dana murah. khususnya pada consumer banking bukan hanya pada commercial dan corporate banking saja agar market share tabungan dan giro meningkat.

3. Meningkatkan digitalisasi layanan perbankan

Selain unsur layanan mudah, murah, cepat dan aman, sisi spritual dan sosial dari layanan digital perlu dikembangkan untuk menjadi pembeda dibandingkan layanan digital bank konvensional seperti penawaran berinfaq disetiap layanan transaksi. Jumlah ATM khususnya setor tunai yang masih sedikit dan sulit ditemukan merupakan salah satu kelemahan Bank Syariah Mandiri. Untuk menigkatkan pertumbuhan DPK, BSM perlu mengoptimalkan fasilitas teknologi informasi. Terobosan teknologi perlu terus dilakukan dalam memudahkan penambahan rekening baru khusunya untuk rekening perorangan.

\section{KESIMPULAN}

Berdasarkan peramalan yang dilakukan, dana pihak ketiga tumbuh pada Tahun 2020 lebih baik daripada tahun-tahun sebelumnya. Metode Exponential Smoothing dengan Holt Winters yang dgunakan pada penelitian ini menunjukkan nilai akurasi yang sangat baik. Deposito non profit sharing masih menjadi dana terbesar akan berada pada nilai Rp. 48.630.000.000.000 dengan probabilitas 95\% yang berada dalam selang kepercayaan Rp. 41.114.110.000.000 dan Rp. 56.148.650.000.000 Nilai akurasi peramalan pada produk ini RMSE sebesar 1.043388 dan nilai MAPE 2.01\%. Untuk giro non profit sharing dari hasil 
peramalan merupakan dana terkecil yang akan diperoleh dengan point of forecast Rp. 3.451.101.000.000 dengan interval kepercayaan Rp. 2.047.071.100.000 dan Rp.4.855.131.000.000 dengan nilai akurasi peramalan sebesar RMSE 0.3264284 dan nilai MAPE $23.83 \%$.

Dengan hasil peramalan yang akurat, Bank Syariah Mandiri dapat menentukan strategi pemasaran yang tepat dalam mempertahankan dan mengembangkan market share Dana Pihak Ketiga

Penelitian lebih lanjut dapat dilakukan dengan menambahkan variabel ekonomi lain yang menjadi leading indicator dan menggunakan metode peramalan yang lain dalam memprediksi pertumbuhan DPK.

\section{DAFTAR PUSTAKA}

Aini LF. (2014). Pengaruh Strategi Pemasaran Terhadap Minat Nasabah Memilih Produk Tabunganku (Studi di Bank Muamalat Indonesia Cabang Serang). Jurnal Ekonomi Islam, 5(1), 1-21. $\quad$ Retrieved from http://www.journal.islamiconomic.or.id/index.php/ijei/article/view/4/4

Assauri, S. (2015). Manajemen Pemasaran. (Rajagrafindo Persada, Ed.) (Manajemen). Jakarta: Rajagrafindo Persada.

Kurniati, I. N. (2015). Forecasting Pertumbuhan Dana Pihak Ketiga. Jakarta. Retrieved from https://www.bi.go.id/id/publikasi/wp/Pages/WP-Nov-2016-1.aspx

Maesari, Ibdaisyah, H. H. (2015). Pengaruh Strategi Pemasaran Produk Tabungan Ib Hasanah Dengan Akad Wadiah Terhadap Tingkat Pertumbuhan Jumlah Nasabah Bni Syariah Cabang Bogor. Al-Infaq Jurnal Ekonoimi Islam, 6(1), 144-200.

Makridakis S dan W, C. S. (1999). Metode dan Aplikasi Peramalan. Binarupa Aksara. (Binarupa Aksara, Ed.). Jakarta: Binarupa Aksara.

Maria, U. (2010). Analisa Perkembangan Asset, Dana Pihak Ketiga (DPK), Dan Pembiayaan Perbankan Syariah Di Indonesia. Universitas Gunadarma. Universitas Gunadarma. $\quad$ Retrieved from https://www.academia.edu/2342612/Analisa_Perkembangan_Asset_Dana_Pihak_Keti ga_DPK_Dan_Pembiayaan_Perbankan_Syariah_Di_Indonesia

Ningrum, E. P., \& Samrotun, Y. C. (2019). NON PERFORMING FINANCING PADA BANK UMUM SYARIAH DI. Jurnal Ekonomi Pembangunan, 5(2), 75-85. Retrieved from https://journal.stiem.ac.id/index.php/jurep/article/view/422/311 Otoritas Jasa Keuangan. (2019). Statistik Perbankan Syariah- Mei 2019. Retrieved from 
https://www.ojk.go.id/id/kanal/syariah/data-dan-statistik/statistik-perbankansyariah/Pages/Statistik-Perbankan-Syariah---Mei-2019.aspx

R. Bakri, U. Data, and N. A. (2019). Aplikasi Auto Sales Forecasting Berbasis Computational Intelligence Website untuk Mengoptimalisasi Manajemen Strategi Pemasaran Produk. Jurnal Sistem Informasi Bisnis, 9(2), 244-251. Retrieved from https://doi.org/10.21456/vol9iss2pp244-251

Sapar Sapar, Nuraeni Nonji, H. S. (2014). PENGARUH RISIKO PEMBIAYAAN MUDHARABAH TERHADAP PROFITABILITAS PADA PT.BANK SYARIAH MUAMALAT INDONESIA Tbk. Jurnal Ekonomi Pembangunan STIE Muhammadiyah Palopo, l(1). Retrieved from https://journal.stiem.ac.id/index.php/jurep/article/view/18

Shumway, R.H., Stoffer, D. . (2011). Time Series Analysis and Its Applications with R Examples. 3nd Springer New York USA.

Sukmana R, S. M. (2007). Forecasting Saving Deposit In Malaysian Islamic Banking: Comparison Between Artificial Neural Network And Arima. Jurnal Ekonomi Dan Pembangunan, 8(2), 154-161. Retrieved from http://journal.umy.ac.id/index.php/esp/article/view/1517/1563

Tias Safitri , Nurkaromah Dwidayati, S. (2017). PERBANDINGAN PERAMALAN MENGGUNAKAN METODE EXPONENTIAL SMOOTHING HOLT-WINTERS DAN ARIMA. UNNES Journal of Mathematics, 6(1), 48-58. Retrieved from http://journal.unnes.ac.id/sju/index.php/ujm

Wulan Lestari Oka, K. I. dan N. (2015). Pengaruh Dana Pihak Ketiga, Penilaian 5c Kredit, Dan Kualitas Kredit Terhadap Keputusan Pemberian Kredit Di PT . Bank Pembangunan Daerah Bali Cabang Singaraja. Ejournal Univ Pendidik Ganesha, 3(1). Retrieved from https://ejournal.undiksha.ac.id/index.php/S1ak/article/view/5247/3977 Yuseva Rismawanti, M. Y. D. (2018). Perbandingan Peramalan Metode Moving Average dan Exponential Smoothing Holt Winter Untuk Menentukan Peramalan Inflasi di Indonesia. Prosiding Seminar Nasional Mahasiswa Unimus, 1, 330-335. 